\title{
RESPONSE OF ALFALFA FORAGE TO PHOSPHORUS, BORON AND MANGANESE BASED FERTILIZING SYSTEMS
}

\section{Maryam Kheirkhah ${ }^{1}$, Hamid Madani ${ }^{2,}$, Shahram Lac $^{3}$, Ghorban Nourmohammadi ${ }^{4}$ and Mani Mojaddam $^{3}$}

\begin{abstract}
${ }^{1}$ Department of Agronomy, College of Agriculture, Khuzestan Science and Research branch, Islamic Azad University, Ahvaz, Iran
${ }^{2}$ Department of Agronomy, College of Agriculture, Arak Branch, Islamic Azad University, Arak, Iran.

3Department of Agronomy, College of Agriculture, Ahvaz Branch, Islamic Azad University, Ahvaz, Iran.

${ }^{4}$ Department of Agronomy, College of Agriculture, Science and Research Branch, Islamic Azad University, Tehran, Iran
\end{abstract}

Received - February 22, 2016; Revision - May 01, 2016; Accepted - June 28, 2016

Available Online - June 30, 2016

DOI: http://dx.doi.org/10.18006/2016.4(4).398.405

\section{KEYWORDS \\ Alfalfa \\ Boron \\ Forage Yield \\ Manganese \\ Phosphate Solubilizing \\ Bacteria}

\begin{abstract}
This study was conducted to explore the effect of phosphate solubilizing bacteria (PSB), boron (Borax and Boric acid) and manganese (manganese chelate and manganese sulfate) based fertilizers on forage production of alfalfa. Experiment was laid in a split plot factorial in the form of randomized complete block design with phosphorus bio-fertilizer rates $\left(0\right.$ and $\left.100 \mathrm{~g}^{-h a^{-1}}\right)$ in main plots, while boron $(0$, Borax foliar application of 1.0 lit.ha $^{-1}$ and Boric acid soil application $10 \mathrm{~kg}^{\text {. ha }}{ }^{-1)}$ and manganese fertilizer $(0$, manganese chelate foliar application 1.0 lit.ha $^{-1}$ and manganese sulfate soil application $10 \mathrm{~kg}$. $\mathrm{ha}^{-1)}$ were used in sub plots. The results showed that the highest dried forage yield was obtain by boron and manganese foliar application and bio-phosphorus utilization about $24.00 \mathrm{t} / \mathrm{ha}$. Thus, triple application of PSB, Mn and B (100 g.ha ${ }^{-1}$ as soil application and 1.0 lit.ha $^{-1}$ of each Mn and B solutions) could be recommended as the best treatment for improve forage yield of alfalfa (cv. Ranger) under the experiment environmental conditions.
\end{abstract}

* Corresponding author

E-mail: h-madani@iau-arak.ac.ir (Hamid Madani)

Peer review under responsibility of Journal of Experimental Biology and Agricultural Sciences.

Production and Hosting by Horizon Publisher India [HPI] (http://www.horizonpublisherindia.in/).

All rights reserved.
All the article published by Journal of Experimental Biology and Agricultural Sciences is licensed under a Creative Commons Attribution-NonCommercial 4.0 International License Based on a work at www.jebas.org.

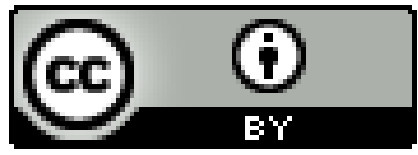




\section{Introduction}

Perennial crops such as Alfalfa (Medicago sativa L.) play an important role in sustainable and dynamic agriculture and human food production. With the attention given to sustainable agriculture in recent decades, there is renewed interest in legumes and cropping systems (Sweeney et al., 2011). Alfalfa is one of the most important forage crops in world and also in Iran. Due to its high yield potential, protein content and palatability, it is widely grown in almost all regions of Iran (Hosseinirad et al., 2013).

For sustainable production of Alfalfa, proper management of biomass yield and total dry matter, soil and foliar application of fertilizers management are required. Along with various fertilizing agents, production of alfalfa is also limited by the deficiency of Boron (Marschner, 1995; Dear \& Wiear, 2004). According to Marschner (1995) boron is one of the micronutrient that required for the normal growth and development of plants and boron deficiency can be reduced the crop yield. Further, Dear \& Wiear (2004) reported that Alfalfa needs more boron as compared to barley crop. Sugar transport, cell wall stability, photosynthesis, nucleic acid metabolism, respiration metabolisms and hormonal activity are the most important plant metabolisms in that boron play a major role (Welch, 1995, Marschner, 1995).

As good as boron, manganese is another necessary important element for the growth and developments of most crop plants (Zhengguo et al., 2009) and its deficiency retarded the crop production in many areas of the world (Eleyan et al., 2014). It is well reported that manganese played a key roles in photosynthesis, oxidation-reduction (redox) and metabolism of nitrogen in plants (Sadana et al., 2005; Inal \& Gunes, 2008). Further, Shenker et al. (2004) reported that an optimal amount of Mn increased growth and chlorophyll content of tomato plants. The use of manganese sulfate fertilizer improves crop production and plant photosynthesis because $\mathrm{Mn}$ is an activator of many enzymes in plant.

In case of fertilizers, peoples are more concern only about the use of nitrogen fertilizers; very few farmers have knowledge about the use of phosphorus fertilizers. Application of phosphorus fertilizer is also essential for crops (Aulakh et al., 2003). Influence of phosphorus fertilization on agronomic performance of alfalfa has been well documented by various researchers (James et al., 1995; Li et al., 1998; Malhi et al., 2001; Reid et al., 2004).
Excess uses of chemical fertilizers are the major problems for modern agriculture system and these are responsible for water and soil contamination. Farmers are seeking for a viable alternative of chemical fertilizers. Phosphate solubilizing bacteria can be applied as safer sources of phosphorus instead of chemical phosphorus fertilizers. Phosphorus can be considered as a growth limiting nutrition due to its low availability to plants because its low solubility and fixation in soil (Soon, 1990; Thomazi et al 1990; Nahas, 2007). Phosphate solubilizing microorganisms have solved this problem to large extend by dissolving insoluble phosphate via production of inorganic or organic acids or by decrease of $\mathrm{pH}$ and bring about the dissolution of bound forms of phosphate, providing available phosphate that can be taken by the plants (Jana, 2007; Mohammadi \& Sohrabi, 2012; Mardad et al., 2013). Among various phosphorus solubilizing microorganisms, phosphate solubilizes bacteria are very useful natural microbes that they can change the soil mineral phosphate to soluble phosphorus by production of organic acids and phosphatases acid (Rodriguez \& Fraga, 1999). Pseudomonas as one of the most important plant growth-promoting bacteria (Singh et al., 2005; Malboobi et al., 2009) can make $70 \%$ of unavailable phosphorus, readily available for plant absorption (Chen, 2006; Kothamasi et al., 2006).

Present study was conducted to explore the effect of simultaneous application of boron, manganese and phosphorus solubilizing bacteria on the nutritional composition and plant growth and development of alfalfa crop in Iran environmental condition.

\section{Materials and Methods}

\subsection{Experimental Site and soil conditions}

This experiment was conducted in 2013 at the research farm of Marv-Dasht in central areas of Fars province, Iran $\left(29^{\circ} 52^{\prime} \mathrm{S}\right.$, $\left.52^{\circ} 48^{\prime} \mathrm{N}\right)$. This site located at 1605 meters above sea level with average annual rainfall of $320 \mathrm{~mm}$ in 2011 and 2012. The maximum and minimum temperatures are 41 and $9{ }^{\circ} \mathrm{C}$, respectively. Initially, field under cultivation of Alfalfa (First year of growing of perennial Alfalfa) were selected for study. Soil samples were collected from the $30 \mathrm{~cm}$ depth and analyzed for estimation of soil physicochemical properties according to the methods described by Ryan et al. (2001). The Soil chemical properties are presented in Table 1 . The 10 year average annual precipitation ranged from $115-141 \mathrm{~mm}$ and the annual average temperature is $25-32^{\circ} \mathrm{C}$ (Hosseinirad et al., 2013).

Table 1. Chemical and physical properties of the soil at the experimental site.

\begin{tabular}{|lcccccccccc|}
\hline Depth $(\mathbf{c m})$ & Soil texture & pH se & $\mathbf{N}(\%)$ & $\mathbf{P}(\mathbf{p p m})$ & $\mathbf{K}(\mathbf{p p m})$ & $\mathbf{B}(\mathbf{p p m})$ & $\mathbf{M n} \mathbf{p p m})$ & OC \% & Ec $(\mathbf{m s})$ \\
\hline $\mathbf{0 - 3 0}$ & $\mathrm{CL}^{*}$ & 7.5 & 0.1 & 15 & 257.9 & 0.67 & 6.1 & 0.37 & 0.96 \\
\hline
\end{tabular}

CL, Clay loam; OC, Organic Matter. 
The treatments were Phosphate solubilizing bacteria (PSB), boron (Borax and Boric acid) and manganese (manganese chelate and manganese sulfate). Experiment was laid in a split plot factorial in the form of randomized complete block design that phosphorus bio-fertilizer rates $\left(0\right.$ and $100{\left.\mathrm{~g} . h a^{-1}\right)}^{-1}$ main plots and boron (0, Borax foliar application of 1.0 lit.ha $^{-1}$ and Boric acid soil application $10 \mathrm{~kg}^{-1 \mathrm{ha}^{-1)}}$ and manganese fertilizer (0, manganese chelate foliar application 1.0 lit.ha $^{-1}$ and manganese sulfate soil application $10 \mathrm{~kg}$. $\mathrm{ha}^{-1)}$ were in sub plots.

Phosphorus bio-fertilizer treatments was a combination of phosphorus solubilizing bacteria Pantoea agglomerans strains P5 and Pseudomonas putida strain P13 included $1 * 10^{9}$ CFU bacteria per 100 grams bio-fertilizer that registered as Barvar $\mathrm{II}^{\circledR}$. For PSB treatments, 100 g.ha ${ }^{-1}$ PSB was mixed in 400 liters of irrigation water and applied manually in soil as fertigation. Boric acid and manganese chelate were foliar application at 2 weeks after each cut stage and Borax and manganese sulfate were applied in soil after the first cut of alfalfa manually in spring.

The Alfalfa cultivar used in this study was Medicago sativa $\mathrm{L}$. cv. Ranger. Total Eighteen plots were imposed in each blocks and a net plot area was $15 \mathrm{~m} 2(3.0 \mathrm{~m}$ in $5.0 \mathrm{~m})$. The irrigation method was conducted by using classic sprinkler irrigation.

\subsection{Sampling and measurements}

Plants were harvested when $10 \%$ of fields crop have flowering. To avoid the marginal effect, the middle rows of each plot were randomly harvested. Samples were cut $4.5 \mathrm{~cm}$ above the soil surface. After harvesting, the samples were dried in electrical oven $\left(72\right.$ hours at $\left.40^{\circ} \mathrm{C}\right)$ and then weighted for forage yield. Samples were sent to the laboratory for determination of nitrogen and protein content by method described by Nelson \& Sommers (1973). Lateral branches of plants were counted manually for each plot.
The achieved data in experiment subjected to the analysis of variance method using SAS (version 9.1.3, 2004) software the means were compared based on Duncan multiple test at $5 \%$ level.

\section{Results and Discussion}

\subsection{Forage yield}

Alfalfa forage yield was significantly influenced by the application of PSB, B and Mn fertilizers either individually or in combination. Results of individual application are represented in table 2 . Results of study suggested that forage yield improved by adding B, Mn and Phosphorus solubilizing bacteria (PSB) especially when Mn was applied. At individual application, highest yield was obtained by using B as foliar application (20.01 t.ha ${ }^{-1}$ ) and soil application B. While the lowest one was related to treatments without any fertilizer $\left(10.40\right.$ t.ha $\left.^{-1}\right)$ and highest yield giving treatment represents $119.58 \%$ increase in forage yield. Boron fertilizer applying in both forms (soil/foliar), made an increase in forage yield (Table 3). Like B, application of PSB also improved plant growth and it is not significantly differ that the foliar application of boron (Table 3). Also, result showed that the interaction of PSB1.BI (22.43 t.ha-1) and B1.Mn1 (21.61 t.ha1) were suitable for producing higher forage yield and it shows superiority over the individual application but are not significantly different.

Using boron whether foliar or soil application without using of PSB didn't show notable effect on forage yield increasing but simultaneous application of boron and PSB resulted $110.06 \%$ in production increasing. In interaction, combined application of PSB1X B1 X Mn1 shows superiority $\left(34 \mathrm{t}^{-h^{-1}}\right.$ ) over the individual or combined application of any two fertilizers (Table 4), and also this treatment increased forage (103.31\%) production in comparison to sample.

Table 2 Means comparison of PSB. B and Mn on studied traits in alfalfa.

\begin{tabular}{|lccccccc|}
\hline SOV & Df & $\begin{array}{c}\text { Forage } \\
\text { yield }\end{array}$ & $\begin{array}{c}\text { Lateral } \\
\text { branches }\end{array}$ & $\begin{array}{c}\text { Nitrogen } \\
\text { of stem }\end{array}$ & $\begin{array}{c}\text { Nitrogen } \\
\text { of leaf }\end{array}$ & $\begin{array}{c}\text { Protein } \\
\text { of stem }\end{array}$ & $\begin{array}{c}\text { Protein } \\
\text { of leaf }\end{array}$ \\
\hline R & 2 & 0.035 & 25020 & 0.035 & 0.019 & 1.394 & 0.744 \\
\hline PSB & 1 & $7.826^{* *}$ & $4417237^{* *}$ & $6.892^{* *}$ & $9.902 * *$ & $269.219^{* *}$ & $386.826^{* *}$ \\
\hline Error(PSB) & 2 & 0.021 & 1114 & 0.005 & 0.001 & 1.107 & 1.055 \\
\hline B & 2 & $15.354^{* *}$ & $6989712^{* *}$ & $7.265^{* *}$ & $36.409^{* *}$ & $283.818^{* *}$ & $1422.248^{* *}$ \\
\hline B.PSB & 2 & $0.79^{* *}$ & $163136^{* *}$ & $0.813^{* *}$ & $0.748^{* *}$ & $31.781^{* *}$ & $29.253^{* *}$ \\
\hline Mn & 2 & $1.358^{* *}$ & $902826^{* *}$ & $1.111^{* *}$ & $1.11^{* *}$ & $43.425^{* *}$ & $43.386^{* *}$ \\
\hline Mn.PSB & 2 & $0.008 \mathrm{~ns}$ & $29007^{*}$ & $0.001^{\mathrm{ns}}$ & $0.022^{\mathrm{ns}}$ & $0.048^{\mathrm{ns}}$ & $0.892^{\mathrm{ns}}$ \\
\hline B.Mn & 4 & $0.083^{* *}$ & $11138^{\mathrm{ns}}$ & $0.091^{* *}$ & $0.026^{\mathrm{ns}}$ & $3.584^{* *}$ & $1.037^{\mathrm{ns}}$ \\
\hline B.Mn.SB & 4 & $0.039^{*}$ & $24659^{*}$ & $0.056^{*}$ & $0.054^{*}$ & $2.05^{*}$ & $1.88^{*}$ \\
\hline Error & 32 & 0.013 & 9068 & 0.018 & 0.017 & 0.735 & 0.667 \\
\hline C.V. & & 3.46 & 7.68 & 5.37 & 3.67 & 5.37 & 3.67 \\
\hline
\end{tabular}

*,**Significant at $\mathrm{P}=0.05$ and $\mathrm{P}=0.01$ levels, respectively. ns: Not Significant. CV: Coefficient Variation 
Table 3 Means comparison of PSB. B and Mn for treats of alfalfa

\begin{tabular}{|c|c|c|c|c|c|c|}
\hline treatments & $\begin{array}{c}\text { Forage } \\
\text { Yield } \\
\text { t.ha }^{-1}\end{array}$ & $\begin{array}{c}\text { Lateral } \\
\text { Branches } \\
\text { \# ha }^{-1}\end{array}$ & $\begin{array}{c}\text { Nitrogen } \\
\text { of stem } \\
\%\end{array}$ & $\begin{array}{c}\text { Nitrogen } \\
\text { of leaf } \\
\%\end{array}$ & $\begin{array}{c}\text { Protein } \\
\text { of stem } \\
\%\end{array}$ & $\begin{array}{c}\text { Protein } \\
\text { of leaf } \\
\%\end{array}$ \\
\hline PSB0 & $14.73^{\mathrm{b}}$ & $954.73^{b}$ & $2.19^{\mathrm{b}}$ & $3.13^{\mathrm{b}}$ & $13.73^{\mathrm{b}}$ & $19.57^{\mathrm{b}}$ \\
\hline PSB1 & $18.54^{\mathrm{a}}$ & $1526.7^{\mathrm{a}}$ & $2.91^{\mathrm{a}}$ & $3.98^{\mathrm{a}}$ & $18.19^{\mathrm{a}}$ & $24.92^{\mathrm{a}}$ \\
\hline B0 & $11.37^{\mathrm{c}}$ & $530.86^{c}$ & $1.84^{\mathrm{b}}$ & $1.92^{b}$ & $11.51^{\mathrm{c}}$ & $12.03^{b}$ \\
\hline B1 & $20.01^{\mathrm{a}}$ & $1697.53^{\mathrm{a}}$ & $3.06^{\mathrm{a}}$ & $4.50^{\mathrm{a}}$ & $19.14^{\mathrm{a}}$ & $28.18^{\mathrm{a}}$ \\
\hline$\overline{\mathbf{B 2}}$ & $18.53^{b}$ & $1493.83^{b}$ & $2.75^{\mathrm{ab}}$ & $4.24^{\mathrm{a}}$ & $17.24^{\mathrm{ab}}$ & $26.53^{\mathrm{ab}}$ \\
\hline Mn0 & $15.19^{b}$ & $1008.64^{c}$ & $2.29^{\mathrm{a}}$ & $3.29^{\mathrm{a}}$ & $14.32^{b}$ & $20.61^{b}$ \\
\hline Mn1 & $17.93^{\mathrm{a}}$ & $1455.55^{\mathrm{a}}$ & $2.78^{a}$ & $3.79^{a}$ & $17.41^{\mathrm{a}}$ & $23.70^{\mathrm{a}}$ \\
\hline Mn2 & $16.76^{\mathrm{ab}}$ & $1258.02^{\mathrm{ab}}$ & $2.58^{\mathrm{a}}$ & $3.58^{\mathrm{a}}$ & $16.15^{\mathrm{a}}$ & $22.42^{\mathrm{ab}}$ \\
\hline PSB0 B0 & $10.68^{\mathrm{d}}$ & $353.09^{f}$ & $1.73^{\mathrm{f}}$ & $1.73^{\mathrm{d}}$ & $10.81^{\mathrm{f}}$ & $10.83^{d}$ \\
\hline PSB0 B1 & $17.59^{\mathrm{b}}$ & $1340.74^{c}$ & $2.57^{\mathrm{c}}$ & $3.96^{\mathrm{b}}$ & $16.07^{\mathrm{c}}$ & $24.74^{b}$ \\
\hline PSB0 B2 & $15.94^{\mathrm{c}}$ & $1170.37^{\mathrm{d}}$ & $2.29^{\mathrm{d}}$ & $3.71^{\mathrm{b}}$ & $14.31^{\mathrm{d}}$ & $23.16^{\mathrm{c}}$ \\
\hline PSB1 B0 & $12.07^{\mathrm{d}}$ & $708.64^{e}$ & $1.95^{\mathrm{e}}$ & $2.12^{\mathrm{c}}$ & $12.21^{\mathrm{e}}$ & $13.24^{\mathrm{d}}$ \\
\hline PSB1 B1 & $22.43^{a}$ & $2054.32^{\mathrm{a}}$ & $3.55^{\mathrm{a}}$ & $5.06^{\mathrm{a}}$ & $22.21^{\mathrm{a}}$ & $31.63^{\mathrm{a}}$ \\
\hline PSB1 B2 & $21.12^{\mathrm{a}}$ & $1817.28^{b}$ & $3.22^{b}$ & $4.79^{\mathrm{ab}}$ & $20.17^{b}$ & $29.91^{\mathrm{a}}$ \\
\hline PSB0 Mn0 & $13.33^{\mathrm{e}}$ & $767.90^{\mathrm{d}}$ & $1.94^{f}$ & $2.90^{\mathrm{e}}$ & $12.15^{\mathrm{f}}$ & $18.16^{\mathrm{d}}$ \\
\hline PSB0 Mn1 & $16.11^{\mathrm{c}}$ & $1155.56^{\mathrm{c}}$ & $2.42^{\mathrm{d}}$ & $3.36^{\mathrm{cd}}$ & $15.14^{\mathrm{d}}$ & $21.02^{\mathrm{c}}$ \\
\hline PSB0 Mn2 & $14.76^{\mathrm{d}}$ & $940.74^{\mathrm{d}}$ & $2.22^{\mathrm{e}}$ & $3.12^{\mathrm{d}}$ & $13.90^{\mathrm{e}}$ & $19.52^{d}$ \\
\hline PSB1 Mn0 & $17.06^{\mathrm{bc}}$ & $1249.38^{\mathrm{c}}$ & $2.64^{c}$ & $3.69^{c}$ & $16.50^{\mathrm{c}}$ & $23.06^{\mathrm{b}}$ \\
\hline PSB1 Mn1 & $19.75^{\mathrm{a}}$ & $1755.56^{\mathrm{a}}$ & $3.15^{\mathrm{a}}$ & $4.22^{\mathrm{a}}$ & $19.68^{\mathrm{a}}$ & $26.39^{a}$ \\
\hline PSB1 Mn2 & $18.81^{\mathrm{b}}$ & $1575.31^{b}$ & $2.94^{\mathrm{b}}$ & $4.05^{b}$ & $18.40^{\mathrm{b}}$ & $25.31^{\mathrm{a}}$ \\
\hline B0 Mn0 & $10.63^{\mathrm{e}}$ & $314.81^{\mathrm{f}}$ & $1.68^{f}$ & $1.73^{\mathrm{e}}$ & $10.51^{\mathrm{f}}$ & $10.81^{\mathrm{e}}$ \\
\hline B0 Mn1 & $12.28^{\mathrm{d}}$ & $759.26^{\mathrm{e}}$ & $1.97^{\mathrm{e}}$ & $2.15^{d}$ & $12.34^{\mathrm{e}}$ & $13.45^{\mathrm{d}}$ \\
\hline B0 Mn2 & $11.22^{\mathrm{e}}$ & $518.52^{\mathrm{e}}$ & $1.87^{\mathrm{e}}$ & $1.89^{\mathrm{e}}$ & $11.68^{\mathrm{e}}$ & $11.81^{\mathrm{de}}$ \\
\hline B1 Mn0 & $17.91^{c}$ & $1414.81^{c}$ & $2.65^{\mathrm{cd}}$ & $4.18^{b c}$ & $16.56^{\text {cd }}$ & $26.13^{b}$ \\
\hline B1 Mn1 & $21.61^{\mathrm{a}}$ & $1925.93^{a}$ & $3.41^{\mathrm{a}}$ & $4.78^{\mathrm{a}}$ & $21.28^{\mathrm{a}}$ & $29.89^{\mathrm{a}}$ \\
\hline B1 Mn2 & $20.52^{\mathrm{a}}$ & $1751.85^{b}$ & $3.13^{b}$ & $4.56^{\mathrm{a}}$ & $19.58^{b}$ & $28.52^{a}$ \\
\hline B2 Mn0 & $17.06^{\mathrm{c}}$ & $1296.30^{d}$ & $2.55^{\mathrm{d}}$ & $3.98^{\mathrm{c}}$ & $15.91^{\mathrm{d}}$ & $24.89^{c}$ \\
\hline B2 Mn1 & $19.91^{\mathrm{b}}$ & $1681.48^{b}$ & $2.98^{\mathrm{b}}$ & $4.44^{b}$ & $18.62^{b}$ & $27.76^{b}$ \\
\hline B2 Mn2 & $18.63^{\mathrm{b}}$ & $1503.70^{\mathrm{c}}$ & $2.75^{\mathrm{c}}$ & $4.30^{b}$ & $17.19^{\mathrm{c}}$ & $26.93^{b}$ \\
\hline
\end{tabular}

Means in same columns followed by the same letter were not significantly different at the 5\% level; PSBO (Treatment without P biofertilizer); B0 (Treatment without Borax); Mn0 (Treatment without Mn); B1 (Foliar application of 1 lit/ha borax); B2 (Soil application of $10 \mathrm{~kg} / \mathrm{ha}$ boric acid); Mn1 (Foliar application of Mn @ 1 lit/ha); Mn2 (Soil application of manganese sulfate @ $10 \mathrm{~kg}$. ha).

These result were coincide with findings of Turan et al. (2010), who clarified that the highest yield of Alfalfa was obtained by using boron fertilizers. Similarly, Ahmed et al. (2010) reported that usage of bio-fertilizers which contains Azotobacter and Pseudomonas significantly have raised production of sorghum. Further, Kohno et al. (2008) reported a meaningfully increased in bean yield by using of manganese fertilizers.

\subsection{Number of lateral branches}

Alfalfa lateral branches per hectare are an effective agent in Alfalfa forage yield enhancing. It was significantly $(\mathrm{P}<0.05)$ influenced by three factors as well as interactions (table 2). The highest number of lateral branches was obtained from triple interaction of B (Foliar), Mn (Foliar) and PSB by 2340.74 branches $\mathrm{ha}^{-1}$ while the lowest one was obtained in control by
592.96 branches $\mathrm{ha}^{-1}$ ) showing more $300 \%$ increase in the number of lateral branches (Table 4). PSB and B rate significantly affected the Number of lateral branches $(\mathrm{P}<0.001)$. The best treatment in PSB and B interaction was recorded from PSB1B1 (Table 3). The Number of lateral branches in this interaction showing a colossal $481.81 \%$ increase compared to PSB0X B0 (Table 3). Also, PSB and Mn interaction effects was significantly affected the Number of lateral branches $(\mathrm{P}<0.05)$. The best treatment in PSB and Mn interaction was recorded from PSB1Mn1, so this treatment was caused $128.61 \%$ increase compared to P0Mn0 (Table 3). It can be concluded that PSB can increase the availability of phosphorus for producing high number lateral branches per hectare. The treatments containing PSB evidently performed better than the treatment without PSB application. 
Application of phosphorus often caused re-growing of shoot parts of Alfalfa in absence drought stress condition (Jiang et al., 2009). The results identified that deficiency of boron in some plants such as Alfalfa, Red Clover, Turnip and some varieties of Cabbage will cause to reduction of production because they need higher amount of this element (Tariq \& Mott, 2007; Sherrell \& Toxopeus, 2012). Further, Reinbott \& Blevins (2008) reported that application of boron and manganese increased number of branches in soybean crops which as a result made increasing in yield and yield component in this plant.

\subsection{Nitrogen content in stem and leaf}

Nitrogen is quantitatively most important nutrient that plants obtain from soil. Well-managed Alfalfa crop effectively absorb mineralized $\mathrm{N}$ from fertilizer and remove residual nitrate from the subsoil, irrigation water, and fix less $\mathrm{N}$ from the air. The value of legumes nitrogen fixing for improving production and higher yield can be achieved to balance soil elements by the application of bio-fertilizers (Kannaiyan, 2002). When two or more elements have a positive interaction with each other, synergistic effects occur. In this experiment, the synergistic relationship between the elements boron, manganese and phosphorus has been created so that these elements have been increased nitrogen uptake by Alfalfa. Triple interaction of B, $\mathrm{Mn}$ and PSB had significant effect $(\mathrm{P}<0.05)$ on nitrogen content in both stem (3.94\%) and leaf $(5.37 \%)$ tissues while the minimum was gained from control (without any fertilizer) (1.5\% and $1.54 \%$ ) showing a colossal $162.97 \%$ and $248.62 \%$ increase in the $\mathrm{N}$ of stem and leaf, respectively (Table 4). At individual application, B is showing superiority over the other treatments while in combination of two, combined application of PSB and B is superior to all other treatments (Table 3). Dual interaction of B. PSB, the best result of leaf nitrogen content was pertained to B1.PSB1 (Table 3). Furthermore, interaction of B X PSB and B X Mn on nitrogen content in alfalfa stems were significant (Table 2), also, the interaction between boron and phosphorous increased $105.4 \%$ nitrogen content in stem rather than treatment B0PSB0 (Table 3). Some studies have recognized a positive correlation between nitrogen accumulation and utilization of phosphorous fertilizer (Waluyo et al., 2004; Turan et al., 2010). Therefore phosphorous not only have important role on forage production but also increased production with intensification of absorbing some elements such as nitrogen. Wicz (2000) studied 38 cultivars of Alfalfa and identified that more appropriate soil fertility and nitrogen concentration in plant tissues have led to better protein digestion and absorption by livestock.

\subsection{Protein content in stem and leaf}

Measurement of protein content as qualitative parameters in alfalfa forage is one of the most important ways to survey Alfalfa standards forage quality. Protein content can estimated through multiplying the nitrogen content by a coefficient conversion (Mariotti et al., 2008). Moreover, Protein content was directly correlated to the dry matter accumulation (Lemaire et al., 1994).

Table 4. Interaction effect of PSB. B. Mn for treats of alfalfa.

\begin{tabular}{|c|c|c|c|c|c|c|}
\hline Treatment & $\begin{array}{c}\text { Forage } \\
\text { Yield } \\
\text { t.ha }^{-1}\end{array}$ & $\begin{array}{c}\text { Lateral } \\
\text { Branches } \\
\text { \# ha }^{-1}\end{array}$ & $\begin{array}{c}\text { Nitrogen } \\
\text { of stem } \\
\%\end{array}$ & $\begin{array}{c}\text { Nitrogen } \\
\text { of leaf } \\
\%\end{array}$ & $\begin{array}{c}\text { Protein } \\
\text { of stem } \\
\%\end{array}$ & $\begin{array}{c}\text { Protein } \\
\text { of leaf } \\
\%\end{array}$ \\
\hline PSB0 B0 Mn0 & $20.40^{\mathrm{f}}$ & $162.96^{\mathrm{g}}$ & $1.50^{\mathrm{g}}$ & $1.54^{\mathrm{g}}$ & $9.38^{\mathrm{h}}$ & $9.63^{\mathrm{h}}$ \\
\hline PSB0 B0 Mn1 & $21.55^{\mathrm{e}}$ & $629.63^{\mathrm{e}}$ & $1.93^{\text {ef }}$ & $2.02^{f}$ & $12.07^{\mathrm{g}}$ & $12.62^{g}$ \\
\hline PSB0 B0 Mn2 & $20.07^{\mathrm{f}}$ & $266.67^{f}$ & $1.758^{\mathrm{f}}$ & $1.64^{\mathrm{g}}$ & $10.98^{\mathrm{h}}$ & $10.22^{\mathrm{h}}$ \\
\hline PSB0 B1 Mn0 & $25.37^{d}$ & $1125.93^{\mathrm{d}}$ & $2.22^{\mathrm{de}}$ & $3.67^{\mathrm{de}}$ & $13.88^{\mathrm{e}}$ & $22.91^{\text {de }}$ \\
\hline PSB0 B1 Mn1 & $29.22^{\mathrm{c}}$ & $1511.11^{b c}$ & $2.86^{c}$ & $4.19^{c}$ & $17.89^{\mathrm{c}}$ & $26.21^{\mathrm{c}}$ \\
\hline PSB0 B1 Mn2 & $28.18^{\mathrm{c}}$ & $1385.19^{\mathrm{c}}$ & $2.63^{\mathrm{d}}$ & $4.01^{\mathrm{cd}}$ & $16.45^{\mathrm{cd}}$ & $25.09^{\mathrm{cd}}$ \\
\hline PSB0 B $2 \mathrm{Mn} 0$ & $24.22^{\mathrm{d}}$ & $1014.82^{\mathrm{d}}$ & $2.11^{\mathrm{e}}$ & $3.51^{\mathrm{e}}$ & $13.20^{\mathrm{f}}$ & $21.95^{\mathrm{e}}$ \\
\hline PSB0 B $2 \mathrm{Mn} 1$ & $27.56^{\mathrm{c}}$ & $1325.93^{\mathrm{c}}$ & $2.47^{\mathrm{d}}$ & $3.88^{\mathrm{d}}$ & $15.47^{\mathrm{d}}$ & $24.25^{\mathrm{d}}$ \\
\hline PSB0 B2 Mn2 & $26.04^{\mathrm{d}}$ & $1170.37^{\mathrm{d}}$ & $2.28^{\mathrm{de}}$ & $3.72^{\mathrm{d}}$ & $14.27^{\mathrm{e}}$ & $23.27^{\mathrm{d}}$ \\
\hline PSB1 B0 Mn0 & $20.85^{\mathrm{f}}$ & $466.67^{\mathrm{f}}$ & $1.86^{\mathrm{f}}$ & $1.92^{g}$ & $11.64^{\mathrm{g}}$ & $12.00^{\mathrm{g}}$ \\
\hline PSB1 B0 Mn1 & $23.00^{\mathrm{e}}$ & $888.89^{\mathrm{e}}$ & $2.02^{\mathrm{e}}$ & $2.28^{f}$ & $12.62^{\mathrm{f}}$ & $14.29^{f}$ \\
\hline $\mathrm{PSB} 1 \mathrm{~B} 0 \mathrm{Mn} 2$ & $22.37^{\mathrm{e}}$ & $770.37^{\mathrm{e}}$ & $1.98^{\mathrm{e}}$ & $2.15^{f}$ & $12.38^{\mathrm{fg}}$ & $13.41^{f}$ \\
\hline PSB1 B1 Mn0 & $30.44^{\mathrm{b}}$ & $1703.7^{b}$ & $3.08^{\mathrm{bc}}$ & $4.69^{b}$ & $19.24^{\mathrm{bc}}$ & $29.36^{b}$ \\
\hline PSB1 B1 Mn1 & $34.00^{\mathrm{a}}$ & $2340.74^{a}$ & $3.95^{\mathrm{a}}$ & $5.37^{\mathrm{a}}$ & $24.68^{\mathrm{a}}$ & $33.58^{\mathrm{a}}$ \\
\hline PSB1 B1 Mn2 & $32.85^{\mathrm{a}}$ & $2118.52^{a}$ & $3.63^{\mathrm{a}}$ & $5.11^{\mathrm{a}}$ & $22.72^{\mathrm{a}}$ & $31.95^{\mathrm{a}}$ \\
\hline PSB1 B2 Mn0 & $29.89^{\mathrm{bc}}$ & $1577.78^{b}$ & $2.98^{\mathrm{c}}$ & $4.45^{\mathrm{bc}}$ & $18.63^{c}$ & $27.84^{\mathrm{c}}$ \\
\hline PSB1 B2 Mn1 & $32.26^{\mathrm{a}}$ & $2037.04^{\mathrm{a}}$ & $3.48^{b}$ & $5.01^{\mathrm{ab}}$ & $21.77^{\mathrm{b}}$ & $31.29^{\mathrm{a}}$ \\
\hline $\mathrm{PSB} 1 \mathrm{~B} 2 \mathrm{Mn} 2$ & $31.22^{b}$ & $1837.04^{b}$ & $3.22^{b}$ & $4.89^{b}$ & $20.12^{b}$ & $30.59^{\mathrm{b}}$ \\
\hline
\end{tabular}

Means in same columns followed by the same letter were not significantly different at the 5\% level; PSBO (Treatment without $\mathrm{P}$ biofertilizer); B0 (Treatment without Borax); Mn0 (Treatment without Mn); B1 (Foliar application of 1 lit/ha borax); B2 (Soil application of $10 \mathrm{~kg} / \mathrm{ha}$ boric acid); Mn1 (Foliar application of Mn @ 1 lit/ha); Mn2 (Soil application of manganese sulfate @ $10 \mathrm{~kg}$. ha). 
Interaction effects of $\mathrm{B}, \mathrm{Mn}$ and $\mathrm{PSB}$ had signification effect on stem and leaf protein contents $(\mathrm{P}<0.05)$. Results revealed that factors which had significant differences in term of nitrogen content in leaf and stem were also had significant differences in term of leaf and stem protein this is the endorsement of the validity of this study which indicated coronation between amount of plant protein and amount of nitrogen in plant tissues.

The highest protein content of stem $(24.67 \%)$ and leaf (33.58\%) was recorded from B (Foliar), Mn (Foliar) and PSB combination (Table 4) while the lowest one are $9.38 \%$ and $9.63 \%$ was gained from control showing a colossal $162.95 \%$ and $248.6 \%$ increase in protein content of stem and leaf, respectively (Table 4). The highest protein content in alfalfa leaf was obtained by B and PSB interaction was concerned to B1PSB1 treatment (31.63\%).

Results of current study revealed B1PSB1 raised $199.22 \%$ of leaf protein in comparison to BOPSB0 significantly. Interaction of B X PSB and BX Mn also had significant effect on protein content of alfalfa stem tissues. The highest stem protein was recorded in B and PSB interaction treatment in B1PSB1 level about $22.21 \%$ by means of increased $105.4 \%$ rather than BOPSB0 (Table 3). Furthermore, The highest interaction between B and $\mathrm{Mn}$ was obtained from B1Mn1 treatment by $22.28 \%$ and $102.47 \%$ growth in stem protein content in comparison to $\mathrm{B} 0 \mathrm{Mn} 0$ (Table 3 ).

Since no information was available about reaction of alfalfa ranger cultivar to studied fertilizers.

Results of study recognized the amount fertilizers include boron, manganese and phosphorus solubilizing bacteria which studied in this research was appropriate because not only the studied treatments didn't show any sign of toxic effects or nutrient deficiency but also they caused notable increasing in alfalfa production and other related characteristics. Also foliar application of boron and manganese was detected as a better method rather than soil application. It was decided that micronutrients elements to be used with foliar application and soil application and explore the effect of these fertilizers on the various growth and growth attributes with minimum toxicity.

\section{Conclusion}

Foliar application of boron, manganese and soil application of phosphorus solubilizing bacteria simultaneously, could be improved alfalfa forage yield significantly and substantially. These elements not only individually improved forage production quality and quantity but also interaction of these three showed superiority advanced in alfalfa forage yield. As an important outcome utilization of mentioned fertilizer management system is recommended for fill the gap between the alfalfa potential yield and average alfalfa forage production in the same condition.

\section{Conflict of interest}

Authors would hereby like to declare that there is no conflict of interests that could possibly arise.

\section{Reference}

Ahmed AG, Orabi S, Gomaa AM(2010) Bio-organic farming of grain sorghum and its effect on growth, physiological and yield parameters and antioxidant enzymes activity. Research Journal of Agriculture and Biological sciences 6:270-279.

Aulakh MS, Pasricha NS, Bahl GS (2003) Phosphorus fertilizer response in an irrigated soybean-wheat production system on a subtropical, semiarid soil. Field Crops Research 80: 99-109. doi:10.1016/S0378-4290(02)00172-7.

Chen J (2006) The combined use of chemical and organic fertilizers and/or bio fertilizer for crop growth and soil fertility. International Workshop on Sustained Management of the SoilRhizosphere System for Efficient Crop Production and Fertilizer Use 16-20 October, 2006 Thailand.

Dear BS, Wiear RG (2004) Boron deficiency in pastures and field crops. NSW Agriculture Available on http://www.agric.nsw.gov.au access on $25^{\text {th }}$ December, 2015.

Eleyan SED, Abodahab AA, Abdallah AM, Rabeh HA (2014) Effect of foliar application of manganese and iron on growth characters, yield and fiber properties of some Egyptian cotton cultivars (Gossypium barbadense L.). International Journal of Agriculture and Crop Sciences 7: 1283-1292.

Hosseinirad A, Chaichi MR, Sadeghpour A (2013) Response of alfalfa seed yield and yield components to phosphorus fertilizing systems and seeding rate at semi-saline soil conditions. Journal of Plant Nutrition 36:491-502. DOI:10.1080/01904167.2012.748070.

Inal A, Gunes A (2008) Interspecific root interactions and rhizosphere effects on salt ions and nutrient uptake between mixed grown peanut/maize and peanut/barley in original saline-boron toxic soil. Journal of Plant Physiology 165: 490-503. doi:10.1016/j.jplph.2007.01.016.

James WF, Barko JW, Eakin HL (1995) Internal phosphorus loading in Lake Pepin, Upper Mississippi River. Journal of Freshwater Ecology 10:269-276. DOI:10.1080/02705060.1995.9663446.

Jana B (2007) Distribution pattern and role of phosphate solubilizing bacteria in the enhancement of fertilizer value of rock phosphate in aquaculture ponds: state-of-the-art. In: Velázquez E, Rodríguez-Barrueco C (Eds.) First International Meeting on Microbial Phosphate Solubilization, Development in Plant and Soil Sciences 102:229-238. DOI: 10.1007/978-14020-5765-6_34 
Jiang HX, Shen YX, Zhai GY, Liu XB, Yuan PX (2009) Effects of phosphate fertilizer on utilization of non-structural carbohydrate in residual tissue of medicago sativa during early regrowth stage. Journal of Acta Pratacultural Science 18: 136141.

Kannaiyan S (2002) Biofertilizers for sustainable crop production. Biotechnology of biofertilizers. Narosa Publishing House, New Delhi, India.

Kohno Y, Foy CD, Fleming AL, Krizek DT (2008) Effect of manganese on concentrations of $\mathrm{Zn}, \mathrm{K}, \mathrm{Ca}$ and $\mathrm{Mg}$ in two bush bean cultivars grown in solution culture. Journal of Plant Nutrition 7:897-909. DOI:10.1080/01904168409363253.

Kothamasi D, Kothamasi S, Bhattacharyya A, Kuhad RC, Babu CR (2006) Arbuscular mycorrhizae and phosphate solubilising bacteria of the rhizosphere of the mangrove ecosystem of Great Nicobar Island, India. Biology and Fertility of Soils 42:358-361. DOI: 10.1007/s00374-005-0035-8

Lemaire G (1994) Growth dynamics and digestibility for two genotypes of Lucerne have different morphology. Management and breeding of perennial Lucerne for diversified purposes, Italy, Roma.

Li R, Volence JJ, Joern BC, Cunningham SM (1998) Effect of phosphorus nutrition on carbohydrate and protein metabolism in alfalfa roots. Journal of Plant Nutrition 21: 459-474.

Malboobi MA, Owlia P, Behbahani M, Sarokhani E, Moradi S, Yakhchali B, Delju A, Morrabi Heravi K (2009) Solubilization of organic and inorganic phosphates by three highly efficient soil bacterial isolates. World Journal of Microbiology and Biotechnology 25:1471-1477. DOI: 10.1007/s11274-0090037-z.

Malhi SS, Zentner RP, Heier K (2001) Banding increases effectiveness of fertilizer $\mathrm{P}$ for alfalfa production. Nutrient Cycling Agro-ecosystems 59:1-11.

Mardad I, Serrano A, Soukri A (2013) Solubilization of inorganic phosphate and production of organic acids by bacteria isolated from a Moroccan mineral phosphate deposit. African Journal of Microbiology Research 7: 626-635.

Mariotti F, Tome D, Patureau MP (2008) Converting nitrogen into protein-beyond 6.25 and jones'factors. Journal of Food Science and Nutrition 48: 177-184.

Marschner H (1995) Mineral nutrition of higher plants. Academic Press, San Diego, California, USA.

Mohammadi K, Sohrabi Y (2012) Bacterial bio fertilizers for sustainable crop production: a review. Research Journal of Agriculture and Biological Sciences 7: 307-316.
Nahas E (2007) Phosphate solubilizing microorganisms: effect of carbon, nitrogen, and phosphorus sources. In: Velázquez E, Rodríguez-Barrueco C (Eds.) First International Meeting on Microbial Phosphate Solubilization, Developments in Plant and Soil Sciences 102:111-115. DOI: 10.1007/978-1-40205765-6_15.

Nelson DW, Sommers LE (1973) Determination of total nitrogen in plant material. Agronomy Journal 65: 109-112. doi:10.2134/agronj1973.00021962006500010033x

Reid CR, Winward DL, Koenig RT (2004) A comparison of liquid phosphoric acid and dry phosphorus fertilizer sources for irrigated alfalfa production on calcareous soils. Journal of Communication Soil Science and Plant Analysis 35:39-50. DOI:10.1081/CSS-120027633.

Reinbott TM, Blevins DG (2008) Response of soybean to foliar-applied boron and magnesium and soil-applied boron. Journal of Plant Nutrition 18: 179-200.

Rodriguez H, Fraga R (1999) Phosphate solubilizing bacteria and their role in plant growth promotion. Journal of Biotechnology Advances 17: 319-339. doi:10.1016/S07349750(99)00014-2.

Ryan J, Estefan G, Rashid A (2001) Soil and Plant Analysis Laboratory Manual. Jointly Published by the International Centre of Agriculture and Research in Dry Areas (ICARDA), Aleppo, Syria and National Agriculture Research Centre (NARC), Islamabad.

Sadana US, Sharma P, Ortiz NC, Samal D, Claassen N (2005) Manganese uptake and Mn efficiency of wheat cultivars are related to Mn-uptake kinetics and root growth. Journal of Plant Nutrition and Soil Science 168: 581-589. DOI: 10.1002/jpln.200420491.

Shenker M, Plessner OE, Tel-Or E (2004) Manganese nutrition effects on tomato growth, chlorophyll concentration, and superoxide dismutase activity. Journal of Plant Physiology 161: 197-202. doi:10.1078/0176-1617-00931.

Sherrell CG, Toxopeus MRJ (2012) Effects of boron applications on yield and boron concentration of Lucerne (Medicago sativa L.) grown on yellow-brown pumice soils. New Zealand Journal of Experimental Agriculture 6:145-150.

Singh KK, Srinivasarao C, Masood A (2005) Root growth, nodulation, grain yield, and phosphorus use efficiency of lentil as influenced by phosphorus, irrigation, and inoculation. Journal of Communications in Soil Science and Plant Analysis 36: 1919-1929.

Soon YK (1990) Solubility and retention of phosphate in soils of north western Canada prairie. Canadian Journal of Soil Science 70: 227 - 237. 
Sweeney DW, Moyer JL, Jardian DJ, Whitney DA (2011) Nitrogen, phosphorus, and potassium effects on grain sorghum production and stalk rot following alfalfa and birdsfoot trefoil. Journal of Plant Nutrition 34:1330-1340.

Tariq M, Mott CJB (2007) The significance of boron in plant nutrition and environment -A Review. Journal of Agronomy 6: 1-10. DOI: 10.3923/ja.2007.1.10.

Thomazi MD, Mello FAF, Arzolla S, Mello FA (1990) Phosphate fixation in soils of the Piracicaba Municipality. Journal of Revista de Agricultura 65: 45 - 53.

Turan M, Ketterings QM, Gunes A, Ataoglu N, Esringu A, Bilgili AV (2010) Boron fertilization of Mediterranean aridisols improves lucerne (Medicago Sativa L.) yields and quality. Journal of Soil and Plant Science 60: 427-436.
Waluyo SH, Lie T, Mannetje L (2004) Effect of phosphate on nodule primordial of soybean (Glycine Max Merrill) in acid soils in Rhizotron experiments. Indonesian Journal of Agricultural Science 5: 37-44.

Welch RM (1995) Micronutrient nutrition of plants. Critical Reviews in Plant Sciences 14: 49-82.

Wicz A (2000) Rumen degradability of crud protein of dried grass and Lucerne forage measured by in Sacco incubation and predicted by near infrared reflectance spectroscopy. Journal of Animal Feed Science and Technology 54: 581- 597.

Zhengguo Z, Longium X, Jinlian X, Chenglun L (2009) Effect of manganese tailing on capsicum growth. Chinese Journal of Geochemistry 28: 427-431 